\title{
Stroke epidemiology based on experience from Krasnik county in eastern Poland
}

\author{
Bartłomiej Drop ${ }^{1, B-D, F}$, Marek Kos ${ }^{2, A}$, Marzena Furtak-Niczyporuk ${ }^{2, E}$ \\ ${ }^{1}$ Department of Informatics and Medical Statistics, Faculty of Health Sciences, Medical University, Lublin, Poland \\ 2 II Faculty of Medicine of the English Division, Department of Public Health, Medical University, Lublin, Poland \\ A - Research concept and design, B - Collection and/or assembly of data, C - Data analysis and interpretation, \\ $D$ - Writing the article, $E$ - Critical revision of the article, F - Final approval of article
}

Drop B, Kos M, Furtak-Niczyporuk M. Stroke epidemiology based on experience from Krasnik county in eastern Poland. Ann Agric Environ Med. 2020; 27(3): 448-455. doi: 10.26444/aaem/110020

\begin{abstract}
Introduction. Cerebrovascular diseases in Poland constitute a bigger threat to life in men than in women, especially after the age of 60. Death rates indicate higher stroke over-mortality in the rural population rather than the urban. At the same time, stroke is the main cause of long-term disability, since half of the patients are unable to independently perform daily activities, which makes them dependent on other people.

Materials and method. The study was conducted in the Independent Public Healthcare Institution in Kraśnik, eastern Poland. It covered the medical records of 1,500 patients, 780 women (52\%) and 720 men (48\%), aged 20-100, diagnosed with cerebral infarction. The patients were hospitalised between 2011-2016 in the Neurology Ward with a Stroke Unit, the Internal Medicine Ward, and the Anaesthetics and Intensive Care Ward.

Results. The stroke patients hospitalised in the Independent Public Healthcare Institution in Kraśnik were residents of urban communes (59.1\% of subjects) and rural communes (40.9\%). The most often diagnosed type of stroke was due to embolism of the cerebral arteries (163.4) in women (63.48\%). In men, the most most often diagnosed type was cerebral infarction due to thrombosis of the cerebral arteries (I63.3; 51.33\%). Stroke in $36.15 \%$ of the female subjects resulted in death. In male subjects, death occurred in $26.11 \%$ of the cases.

Conclusions. Women aged around 78-years-old were the most likely to suffer a stroke. In men, it occurred eight years earlier. Despite residents of urban areas being hospitalised due to stroke more often, deaths caused by this disease were recorded the most frequently among rural residents. It can be concluded that primary stroke prevention is the only effective measure for reducing morbidity and premature mortality in the population.
\end{abstract}

\section{Iey words}

stroke, hospitalisation, district hospital, urban commune, rural commune

\section{INTRODUCTION}

Stroke is defined as a more-or-less sudden onset of neurological symptoms caused by circulatory disorders in the brain, resulting from organic or functional changes [1]. The occurrence of focal or generalised cerebral dysfunction is defined as stroke when the symptoms persist for more than 24 hours - if they do not cause an earlier death - and have no other cause than vascular $[2,3,4,5]$. Ischaemic stroke occurs when the blood flow in an extracranial or intracranial artery is impeded or blocked, resulting in a decrease in regional blood flow and changes in microcirculation, leading to nervous cell death [6]. The focal symptoms of ischaemic stroke can include:

- higher nervous function disorders (aphasia-type speech disorders, numeracy skills disorders, reading disorders, hemiplegia, apraxia/dyspraxia);

- vision disorders, taking the form of diplopia or visual field restriction;

- facial and limb paresis, usually of a hemiplegic nature;

- walking difficulties;

- isolation or accompanying sensory disorders $[2,6]$.

Address for correspondence: Marek Kos, Medical University of Lublin, II Faculty of Medicine of the English Division, Department of Public Health, Lublin, Poland E-mail:marekkos@op.pl

Received: 27.11.2018; accepted: 13.05.2019; first published: 17.06 .2019
Risk factors for ischaemic stroke include non-modifiable and modifiable factors. Non-modifiable factors include:

- age (especially in people over the age of 55 in whom the risk of stroke is doubled, and the risk increases every 10 years); - gender (men are $24-30 \%$ more likely to have a stroke in the younger age groups than women, who predominate only after 80 years of age);

- race (a 2.4 times higher incidence of stroke among black people than among white, and twice as high in LatinAmericans as in white people, and a higher risk among Asians);

- genetic load/heredity (a 1.9 times higher risk in the firstdegree relatives of stroke patients than in the general population) $[2,6,7,8,9,10,11,12]$.

On the other hand, modifiable factors include:

- hypertension (the probability of stroke increases proportionally to the value of arterial pressure, especially systolic blood pressure, with the risk increasing by 3-5 times);

- diabetes (the increase in the risk of stroke in patients with diabetes ranges from 1.5-3.0 times, and chronic hyperglycaemia facilitates atherosclerotic arterial remodelling);

- heart diseases (usually atrial fibrillation, myocardial infarction, dilated cardiomyopathy, heart failure, endocarditis, which lead to a 5-18 times higher risk); 
- lipid metabolism disorders (increased levels of LDL cholesterol and triglycerides increase the risk of cardiovascular incidents, with the risk increasing by $1-2$ times);

- lifestyle (physical inactivity, with the risk increasing by 2.7 times);

- smoking (risk increases by $1.5-2.5$ times);

- alcohol abuse (the risk increases by 1-3 times);

- as well as poor diet, obesity, drug addiction, negative impact of social environment and lifestyle, and a history of transient ischaemic attack (in about $50 \%$ of patients a stroke occurs within 48 hours of an ischaemic attack) [2, $6,7,8,9,10,11,13]$.

Stroke is among the main causes of morbidity, mortality, and long-term disability $[14,15,16]$, and every year, stroke affects 15 million people worldwide and causes 5.5 million deaths, of which three million are women and 2.5 million men, and leaves five million people permanently disabled $[17,18]$. Ischaemic stroke accounts for about $85 \%$ of all cases of cerebrovascular diseases [19]. A total of 432,904 deaths caused by stroke were reported in the EU Member States, which accounted for about $9 \%$ of all deaths in 2013. [20]. The highest share of stroke incidence in all deaths was recorded in Bulgaria (19.7\%), Romania (18.7\%), Latvia (17.0\%), Croatia and Lithuania (14.3\% each), and Greece (13.4\%) [20]. The lowest rate pertained to France (5.7\%), Denmark (6.4\%), as well as Belgium and Germany (6.5\% each) [20]. In 2013, the standardised death rate per 100,000 people due to stroke in the European Union Member States was 96 for men and 82 for women [14]. Since 2000, a downward trend in the number of deaths has been observed in the European Union, from $11.5 \%$ in 2000 to $8.7 \%$ in 2013 [17, 20].

In Poland, cardiovascular diseases are the main cause of death, accounting for about $45 \%$ of deaths, of which approximately $18 \%$ are cerebrovascular diseases (2014) [21]. The number of deaths caused by stroke in Poland decreased from $11.3 \%$ in 2000 to $8.5 \%$ in 2013. [20]. As early as 2014, the number of deaths caused by cerebrovascular diseases (I60-I69) had decreased to 80.6 per 100,000 people, which was corroborated by the actual death rate [21]. A downward trend was also observed in the standardised death rate per 100,000 people due to cerebrovascular diseases, which decreased from 58.3 in 2013 to 53.8 in 2014 [21].

\section{OBJECTIVE}

The aim of this study was to analyse the types and prevalence of stroke among the residents of urban and rural areas hospitalised in Kraśnik county, eastern Poland.

\section{MATERIALS AND METHOD}

The study was conducted between 2011-2016 among stroke patients hospitalised in the Neurology Ward with a Stroke Unit, the Internal Medicine Ward and the Anaesthetics and Intensive Care Ward of the Independent Public Healthcare Institution in Kraśnik. The study was based on an analysis of the medical records of patients diagnosed with stroke classified as cerebrovascular diseases (I60-I64) according to the International Statistical Classification of Diseases and Related Health Problems (ICD 10) [22]. The diagnoses included:
- I60. Subarachnoid haemorrhage from carotid siphon and bifurcation;

- I60.0. Nontraumatic subarachnoid haemorrhage from carotid siphon and bifurcation;

- I60.1. Subarachnoid haemorrhage from the middle cerebral artery;

- I60.2. Subarachnoid haemorrhage from the anterior communicating artery;

- I60.3. Subarachnoid haemorrhage from the posterior communicating artery;

- I60.4. Subarachnoid haemorrhage from the basilar artery;

- I60.5. Subarachnoid haemorrhage from the vertebral artery;

- I60.6. Subarachnoid haemorrhage from other intracranial arteries - multiple involvement of intracranial arteries;

- I60.7. Subarachnoid haemorrhage from the intracranial artery, unspecified - ruptured (congenital) berry aneurysm NOS, subarachnoid haemorrhage from the cerebral communicating artery NOS;

- I60.8. Other subarachnoid haemorrhage - meningeal haemorrhage, rupture of a cerebral arteriovenous malformation;

- I60.9. Subarachnoid haemorrhage, unspecified - ruptured (congenital) cerebral aneurysm NOS;

- I61.0. Intracerebral haemorrhage in the hemisphere, subcortical - deep intracerebral haemorrhage;

- I61.1. Intracerebral haemorrhage in the hemisphere, cortical - cerebral lobe haemorrhage, superficial intracerebral haemorrhage;

- I61.2. Intracerebral haemorrhage in the hemisphere, unspecified;

- I61.3. Intracerebral haemorrhage in the brain stem;

- I61.4. Intracerebral haemorrhage in the cerebellum;

- I61.5. Intracerebral haemorrhage, intraventricular;

- I61.6. Intracerebral haemorrhage, multiple localised;

- I61.8. Other intracerebral haemorrhage;

- I61.9. Intracerebral haemorrhage, unspecified;

- I62. Other nontraumatic intracranial haemorrhage;

- I62.0. Subdural haemorrhage (acute) (nontraumatic);

- I62.1. Non-traumatic extradural haemorrhage - nontraumatic epidural haemorrhage;

- I62.9. Intracranial haemorrhage (non-traumatic), unspecified;

- I63. Cerebral infarction, includes occlusion and stenosis of the cerebral and precerebral arteries, resulting in cerebral infarction;

- I63.0. Cerebral infarction due to thrombosis of the precerebral arteries;

- I63.1. Cerebral infarction due to embolism of the precerebral arteries;

- I63.2. Cerebral infarction due to unspecified occlusion or stenosis of the precerebral arteries;

- I63.3. Cerebral infarction due to thrombosis of the cerebral arteries;

- I63.4. Cerebral infarction due to embolism of the cerebral arteries;

- I63.5 Cerebral infarction due to unspecified occlusion or stenosis of the cerebral arteries;

- I63.6. Cerebral infarction due to cerebral venous thrombosis, nonpyogenic;

- I63.8. Other cerebral infarction; I63.9 Cerebral infarction, unspecified;

- I64. Stroke, not specified as haemorrhage or infarction, cerebrovascular accident NOS [22]. 
The studied group of patients came from 10 communes in Kraśnik county, seven of which were rural communes, one urban commune, and two urban-rural communes. According to 2016 data from the Statistical Office in Lublin, the county was inhabited by 97,069 people, 49,825 of whom were women (51.33\%) [23]. Rural communes were inhabited by 44,546 people, of whom $50.44 \%$ were women. Urban and urbanrural communes were inhabited by 52,523 people $(52.08 \%$ women) [23]. $45.89 \%$ of the total population of the county lived in rural communes, while $45.15 \%$ of the population lived in two towns - Kraśnik and Annopol.

In statistical terms, the study results (after calculating the percentage) are presented in Tables and illustrated in Figures. The statistical analysis employed statistical hypothesis verification based on non-parametric tests: the Student's t-test, Mann-Whitney U-test, Kruskal-Wallis test and Pearson's chi-squared test. The significance of the relationships between the analysed characteristics was found to be $\mathrm{p}<0.05[17,25]$. The study results were compiled using STATISTICA 13.1, by STATSOFT, 2017 version.

The medical records were analysed of all 1,500 patients hospitalised in the analysed wards, 80 women (52\%) and 720 men (48\%), diagnosed with cerebral infarction. The patients were aged between 20-100, with the youngest subject under analysis being 25 years old, and the oldest 100 . The average age was 74.4 , and standard deviation -25 years. The youngest woman was 29 , and the oldest 100 . The youngest male subject was 25 , and the oldest 96 . Patients aged 80-90 constituted the largest group (32.33\%) (Fig. 1).

The results of the study revealed that the average age of men affected by a stroke was 70.4, which was significantly lower than in the case of women $-78.1(p<0.001)$. Stroke patients hospitalised in the Independent Public Healthcare Institution in Kraśnik were residents of urban communes (884 patients, $59.1 \%$ ) and rural communes (611 patients, $40.9 \%$ ).

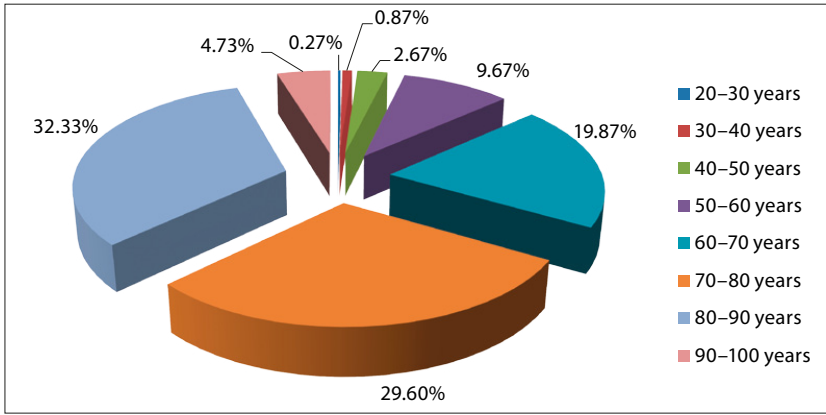

Figure 1. Age distribution of the studied patients

\section{RESULTS}

Women with cerebral infarction due to embolism of the cerebral arteries (I63.4) constituted the largest group (63.48\%) of the 1,500 individuals studied. In men, the most often diagnosed type was cerebral infarction due to thrombosis of the cerebral arteries (I63.3) (51.33\%). The obtained results were statistically significant $(p=0.000210)$. The average age of the patients with cerebral infarction due to embolism of the cerebral arteries (I63.4) was 80.5, whereas the average age of patients with cerebral infarction due to thrombosis of the cerebral arteries (I63.4) was 73.9. In the case of intracerebral haemorrhage in the hemisphere, subcortical
- deep intracerebral haemorrhage (I61.0), the average age of the patients was 72.8. The lowest age average (68.6) concerned patients diagnosed with other types of stroke (I60). The results of the Kruskal-Wallis test were statistically significant $(\mathrm{p}=0.001)$.

Patients were hospitalised the longest in the Neurology Ward (average 15.7 person-days), compared with other wards (average 14.3 days). The Mann-Whitney U-test revealed a significant correlation between the number of person-days and the ward to which the patients were admitted ( $p=0.008)$.

Stroke was fatal for $31.33 \%$ of the patients, with mortality higher in women than in men. Stroke resulted in death in $36.15 \%$ of the female subjects. In male subjects, death occurred in $26.11 \%$ of cases (Tab. 1). A significant correlation was observed between gender and death $(\mathrm{p}=0.000028)$.

Table 1. Deaths caused by stroke according to gender

\begin{tabular}{|c|c|c|c|}
\hline \multirow{2}{*}{ Gender } & \multicolumn{2}{|c|}{ Death } & \multirow{2}{*}{ Total } \\
\hline & Yes & No & \\
\hline \multirow{2}{*}{ Women } & 282 & 498 & 780 \\
\hline & $36.15 \%$ & $63.85 \%$ & $100.00 \%$ \\
\hline \multirow{2}{*}{ Men } & 188 & 532 & 720 \\
\hline & $26.11 \%$ & $73.89 \%$ & $100.00 \%$ \\
\hline \multirow{2}{*}{ Total } & 470 & 1030 & 1500 \\
\hline & $31.33 \%$ & $68.67 \%$ & $100.0 \%$ \\
\hline
\end{tabular}

Pearson's chi-squared: $17.5504, \mathrm{df}=1 ; \mathrm{p}=0.000028$

The most common cause of patients' deaths was intracerebral haemorrhage in a hemisphere, subcortical deep intracerebral haemorrhage (I61.0; 47.74\%). The least number of deaths were recorded in patients with cerebral infarction due to thrombosis of the cerebral arteries (I63.3; $25.56 \%)$.

In the analysed 2011-2016 period, the percentage of deaths among stroke victims was as follows: $2016-36.16 \%, 2014$ $32.42 \%, 2013-31.96 \%, 2015-31.50 \%, 2011-27.95 \%$, and in $2012-27.68 \%$. Deaths were most frequently recorded with respect to the residents of rural areas (34.70\%), compared to the residents of urban areas (29.07\%) (Tab. 2). A significant correlation was observed between the place of residence and death $(\mathrm{p}=0.021213)$.

Table 2. Deaths caused by stroke according to place of residence

\begin{tabular}{|c|c|c|c|}
\hline \multirow{2}{*}{ Place of residence } & \multicolumn{2}{|c|}{ Death } & \multirow{2}{*}{ Total } \\
\hline & Yes & No & \\
\hline \multirow{2}{*}{ Urban area } & 257 & 627 & 884 \\
\hline & $29.07 \%$ & $70.93 \%$ & $100.00 \%$ \\
\hline \multirow{2}{*}{ Rural area } & 212 & 399 & 611 \\
\hline & $34.70 \%$ & $65.30 \%$ & $100.00 \%$ \\
\hline \multirow{2}{*}{ Total } & 469 & 1026 & 1495 \\
\hline & $31.37 \%$ & $68.63 \%$ & $100.0 \%$ \\
\hline
\end{tabular}

Pearson's chi-squared: $5.30923, \mathrm{df}=1 ; \mathrm{p}=0.021213$

Treatment of the patients following their hospitalisation in the Neurology Ward was continued in $25.53 \%$ of the cases. Patients usually continued their treatment in the Rehabilitation Ward (19.53\%) and in the Nursing and Care Ward (6.00\%). Patients who suffered from cerebral infarction due to thrombosis of the cerebral arteries (I63.3) constituted 
the largest group in the Rehabilitation Ward (22.78\%). Patients diagnosed with cerebral infarction due to embolism of the cerebral arteries (I63.4) constituted the largest group in the Nursing and Care Ward (9.22\%). Women most often continued treatment both in the Rehabilitation Ward (68.89\%) and in the Nursing and Care Ward (50.67\%). A significant correlation between the continuation of treatment and gender was observed $(\mathrm{p}=0.003933)$. The oldest patients continued their treatment in the Nursing and Care Ward (average age 82.9). A significantly lower age was observed regarding continuation of treatment in the Rehabilitation Ward (average age 72.2) (Fig. 1). The results of the KruskalWallis test demonstrated significant differences in subjects' age in terms of the continuation of treatment $(\mathrm{p}=0.001)$. Patients in the Nursing and Care Ward continued their treatment for 29.4 person-days, on average, and in the Nursing and Care Ward for 16.5 person-days. The obtained results were statistically significant $(p=0.001)$. The rest of the patients (43.13\%), following their hospitalisation in the Neurology Ward, were discharged home or continued treatment in another hospital.

Table 3. Subjects' age in terms of continuation of treatment

\begin{tabular}{lccccccc}
\hline \multirow{2}{*}{$\begin{array}{l}\text { Continuation } \\
\text { of treatment }\end{array}$} & $\mathrm{N}$ & \multicolumn{4}{c}{ Age of subject (years) } & \multicolumn{2}{c}{ Kruskal-Wallis test } \\
\cline { 2 - 6 } & & $\bar{x}$ & $\mathrm{SD}$ & Min & Max & $\mathrm{H}$ & $\mathrm{p}$ \\
\hline NCW & 90 & 82.9 & 8.7 & 53 & 96 & & \\
\hline REH & 293 & 72.2 & 10.2 & 39 & 94 & 76.52092 & $<0.001$ \\
\cline { 1 - 5 } Total & $\mathbf{3 8 7}$ & $\mathbf{7 4 . 4}$ & $\mathbf{1 2 . 0}$ & $\mathbf{3 9}$ & $\mathbf{9 6}$ & & \\
\hline
\end{tabular}

The oldest patients continued their treatment in the Nursing and Care Ward (average age 82.9). A significantly lower age for the continuation of treatment was observed in other wards (average age 74.3), and the lowest recorded in the Rehabilitation Ward (Tab. 3).

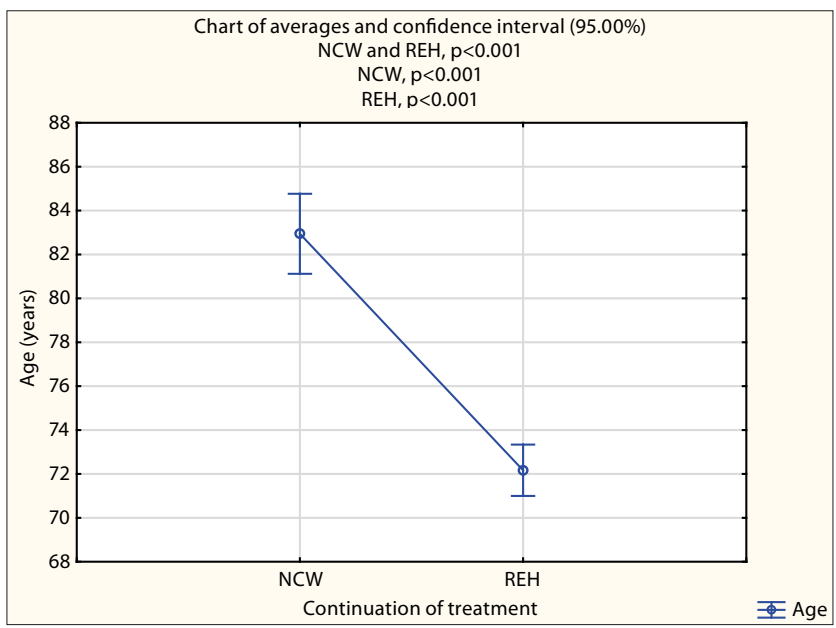

\section{DISCUSSION}

According to data from the National Health Fund, the number of stroke cases recorded in Poland decreased from 94,963 in 2009 to 89,912 in 2014 [26]. In 2011, the structure of the diagnosed cases of stroke was:

- I61.0. - I64. most often (treatment in a stroke ward $>7$ days) concerned cerebral infarction;
- I63.9. unspecified - $20 \%$ of cases;

- I63.5. cerebral infarction due to unspecified occlusion or stenosis of the cerebral arteries $-19.73 \%$ of cases;

- I63.3. cerebral infarction due to thrombosis of the cerebral arteries $-18.50 \%$ of cases;

- I63.8. other cerebral infarction $-11.90 \%$ of cases;

- I63.4. cerebral infarction due to embolism of the cerebral arteries $-11.47 \%$ of cases [27].

The results of the study demonstrated that the most often diagnosed type of stroke was due to embolism of the cerebral arteries (I63.4) in women (63.48\%). In men, the most often diagnosed type was cerebral infarction due to thrombosis of the cerebral arteries (I63.3) (51.33\%). In this study, stroke affected women more often (52\%) than men (48\%).

In 2014 in Poland, the death rate per 100,000 people due to cerebrovascular diseases (I60 - I69) was higher for women (88.8) than for men (71.8) [21]. In principle, this resulted from the age structure because the women were older. The study results also demonstrated that deaths caused by stroke were more often concerned women (36.11\%) than men (26.11\%). However, after eliminating differences in both age structures, it turns out that cerebrovascular diseases constitute a much greater threat to men's lives than to women's lives. This is confirmed by the standardised death rate per 100,000 people due to cerebrovascular diseases (I60 - I69) in Poland, which in 2013 indicated 69.5 for men and 49.2 for women, and in 201464.2 and 45.3, respectively [21]. Furthermore, the study demonstrated higher stroke over-mortality in the rural population $(34.7 \%)$ rather than the urban $(29.07 \%)$. This was confirmed by the standardised death rate per 100,000 people in Poland, which in 2014 was 59.6 for rural areas and 50.4 for urban areas [21]. In 2014, this rate per 100,000 people was higher for men in rural areas, and amounted to 70.6, while for women it was 50.1 [21]. With respect to the regions of Poland, the highest death rate per 100,000 people due to cerebrovascular diseases was recorded between 2013-2014 for the Łódz Province (70.6), Silesian Province (63.4) and the Mazurian Province (59.6) [21].

The marked decrease in the number of deaths attributable to stroke among the residents of the European Union, including Poland, has resulted from the reduction in lifestyle risk factors [28]. This was due, first and foremost, to a change in eating habits, reducing the consumption of animal fats in favour of vegetable fats, increasing the consumption of vegetables and fruit, and cutting down on tobacco-smoking, as well as on high alcohol use $[11,29]$. Furthermore, significantly better access to high-quality post-stroke patient care has resulted in a drop in the death rate within 30 days from admission to hospital. From 2003-2013, this rate decreased from $10.4 \%$ to $9.4 \%$ for the EU Member States [17]. The lowest rates were recorded in Finland and Italy (approx. 5.1\% each), while the highest were found in Latvia (18.4\%) and Slovenia (13.2\%) [17].

At present, social problems, such as increasing obesity and diabetes, are perceived as threats to furthering the fight against cerebrovascular diseases, including stroke $[30,31$, 32]. Primary prevention aimed at reducing the risk of first stroke should play an important role in this respect. In particular, this type of prevention consists in treating risk factors and diseases associated with a higher incidence of stroke [33, 34, 35, 36, 37]. Furthermore, with hypertension being the most important risk factor of stroke, drugs from 
the basic groups, such as thiazides and beta blockers, prove effective in the primary prevention of stroke $[27,38,39]$. It is also worth noting that stroke incidence is on the increase due to the ageing of the European population [40, 41, 42, 43]. In accordance with Population Projections for Poland 2008-2035, the share of people aged $60+/ 65+$ in the total population structure will increase from $16.2 \%$ in 2008 to $26.7 \%$ in 2035 , with an increase from $16.7 \%-27.8 \%$ in urban areas, and from $15.5 \%-25.2 \%$ in rural areas [44]. Therefore, along with the growth in the population of people over the age of 60 , the risk of stroke, which most often affects this age group, will also increase [45]. In accordance with the results of this study, the average age of men diagnosed with stroke was 70.4, which was significantly lower than the age of 78.1 for women. Therefore, given the changing age structure of the Polish population, preventive measures should be taken in respect of stroke.

For several years in Poland, activities in the field of preventing premature morbidity and mortality due to cerebrovascular diseases have been the main focus of national health policy. The National Stroke Prevention and Treatment Programme, launched in 1997, was the implementation of the Helsingborg Declaration, drafted in 1995 for the World Health Oganization (WHO), and specified the principles of the modern treatment of stroke in all European Union countries [46, 47, 48, 49]. In 2003, within the National Programme of Prophylaxis and Treatment of Cardiovascular Diseases (POLKARD), which was continued as the National Programme for Equalising Access to Preventive Measures and Treatment of Cardiovascular Diseases, attempts were made to integrate the fields of medicine dealing with the treatment of cardiovascular diseases for common prevention, entailing a comprehensive approach to all risk factors and popularising modern, integrated procedures in cardiovascular diseases $[50,51]$. Other activities aimed at preventing and reducing the effects of cerebrovascular diseases included redirecting EU funds for Regional Operational Programmes in Poland for the National Programme for the Prevention of Cerebrovascular Diseases (ICD 10:I60-I69) for 2017-2020 [52]. All these measures are intended to level the differences in stroke care in Poland, in comparison to other European countries [24, 53].

European Union Member States are initiating joint efforts to prevent and treat stroke [49]. This can be exemplified by the activities of the European Stroke Organisation (ESO), among others, within the Enhancing and Accelerating Stroke Treatment (ESO-EAST) programme [54]. This is the first comprehensive programme aimed at improving the treatment of stroke in Europe. The ESO-EAST programme was initiated by the European Stroke Organisation and is being implemented in Eastern European countries through the participation of stroke specialists, professional organisations and local authorities in all those countries [51]. The implementation of the programme started in 2015 and will be concluded in 2019. Its objective is to facilitate cooperation with selected physicians from Eastern European countries in order to optimise and implement best practices in the field of stroke care. The goals of the activities of the healthcare units, within the network of entities cooperating under the project, are to improve the outcomes for patients after stroke through scaled-up evidence-based treatments; to decrease disparities in stroke care in Eastern countries compared to Western European countries, to improve the quality of stroke healthcare systems across diverse countries, improve the current clinical practice and health services, improve access to and conditions of health-care staff in professional training, increase research knowledge and performance of health professionals, and develop the methodology of stroke care $[49,54]$.

Stroke is a life-threatening condition which requires immediate and professional hospital treatment [55]. As recommended by the Polish Neurological Society, the treatment of all stroke patients should take place in specialised stroke wards/units where, thanks to brain imaging techniques - computed tomography (CT) and magnetic resonance imaging (MRI) - it is possible to quickly diagnose whether the stroke is of an ischaemic or haemorrhagic type $[39,56,57]$.

In Poland, a comprehensive network of stroke entities is in place, and most patients diagnosed with stroke are treated in such specialist centres $[58,59,60]$. Treating stroke patients in a stroke unit makes it possible to reduce the number of general medical complications, limit the severity of poststroke disability, begin early rehabilitation, reduce early and remote mortality, shorten hospitalisation, decrease treatment costs, and to promptly implement the appropriate secondary prevention measures [27, 61].

At the same time, it should be emphasised that achievement of the desired effects involving lower mortality or disability among stroke patients requires establishing a close cooperation between stroke ward teams and rescue services, ICUs, neuroradiologists, neurosurgeons, anaesthesiologists and physiotherapists [62]. Attention should also be drawn to the role of patients and their families in cooperating and making decisions with the physicians to improve patient care [63].

Secondary prevention plays an important role in this respect. Its objective is to prevent relapse, i.e. another stroke, after a cerebrovascular incident $[49,64]$. In the case of ischaemic stroke, the risk of relapse is $10-12 \%$ in the first year (the highest risk observed immediately after the stroke - more than 3\% of the cases within 30 days), and 5-8\% in each subsequent year [27]. The recurrent stroke risk within five years is $30 \%-40 \%$, of which $15 \%$ of patients can also be affected by heart attacks, and a similar percentage of patients are likely to die of vascular diseases [27]. In the case of cerebral haemorrhages, the risk of recurrent haemorrhage is 3-7\% within the first year, and $19 \%$ within five years [27]. The relapse frequency depends on the subtype of stroke and is the highest in patients who have suffered from stroke due to embolism of cardiac origin, and in cases of a significant stenosis of the carotid arteries [27]. At the same time, high blood pressure is a high-risk factor for patients in all age groups, which further increases the risk of recurrent stroke $[65,66,67]$.

The fact that stroke is the main cause of disability among patients can hardly be neglected, and is therefore associated with serious clinical sequelae, as well as social and economic consequences. Stroke can affect people as early as in their forties, causing disabilities in the most productive years of professional activity [64]. It is estimated that nearly half of the patients who survive the acute phase of stroke are unable to independently perform daily activities, and are dependent on other people [27, 68,69]. Among those who survive more for than six months after stroke, $48 \%$ are affected by haemiplegia, $22 \%$ are unable to walk, $24-53 \%$ are partly or completely dependent on other people and require assistance in basic everyday activities, and $12-18 \%$ suffer from aphasic speech disorders [52]. 
Stroke also has other sequelae, such as post-stroke epilepsy, depression, dementia and fall-induced injuries [27, $70,71]$. As a result, stroke leads to temporary or long-term incapacity to work. In 2012, regarding all insured persons at risk of becoming incapable of work, the Social Insurance Institution (ZUS) recorded 12,605,600 days of absence from work due to cardiovascular diseases, with cerebrovascular diseases (I60-I69) accounting for around $8 \%$ of the cases [27]. In the group of cerebrovascular diseases, cerebral infarction (I63), which resulted in 311,800 days of sickness absence, was the second most common cause of sick leave, especially among men (around 73\%). People aged 50-59, of whom $51.5 \%$ were women and $46.6 \%$ men, constituted the most numerous group (48.5\%) in the structure of persons on sick leave due to incapacity for work resulting from cerebrovascular diseases, who obtained at least one medical certificate in 2012.

Other significant groups included people aged 40-49 (18.8\%), of whom $23.9 \%$ were women and $15.6 \%$ men, and those aged $60-64(15.9 \%)$, of whom $22.2 \%$ were men and $5.7 \%$ women. If the person is still incapable of working after receiving sick pay, but with whom treatment and rehabilitation the ability to work can be regained, ZUS refers such a person to these services. In 2012, ZUS issued 1,674 first-time certificates entitling persons to obtain rehabilitation services due to cerebrovascular diseases (I60-I69) [27]. Around 18\% of these certificates were issued to patients who had suffered from cerebral infarction (I63), and who had an average age of 50.6. Most certificates were issued for a period of 4-6 months (60\%). On the other hand, in 2012, as a result of the sequelae of cerebrovascular diseases, ZUS issued 2,513 first-time certificates, 19\% of which were due to cerebral infarction (I63), granting work incapacity pensions [27]. The degree of incapacity for work cited in the decisions issued due to cerebral infarction indicated that $22.4 \%$ of the people were completely incapable of both working and independent living, $46.4 \%$ were completely incapable of working, and $31.2 \%$ were partially incapable of working [27]. On the other hand, in 2012, ZUS issued 11,571 review certificates, $14 \%$ of which were due to cerebral infarction (I63), granting work incapacity pensions [19]. In Poland, public expenditures on disability pensions incurred in 2010 due to cerebrovascular diseases amounted to PLN $609,716,200$ [27]. In the Lublin Province of eastern Poland, these expenditures amounted to PLN 35,590,600 (75\% for men and $25 \%$ for women), of which pensions due to cerebral infarction (I63), worth PLN 3,106,100, constituted the largest part [27]. On the other hand, in 2014, ZUS recorded a decrease of 253,600 days in absenteeism due to cardiovascular diseases, compared to 2012 , which constituted $5.8 \%$ of all cases of absenteeism [21]. The largest group of people on sick leaves due to cardiovascular diseases were still men (approx. 67\%); however, their number was 6\% lower than in 2012.

\section{CONCLUSIONS}

1. People living in urban areas were affected by stroke more often than those in rural areas.

2. The incidence of stroke was slightly higher among women than among men.

3. Stroke affected men at the age of 70.4, which was significantly lower than in the case of women - 78.1.
4. Cerebral infarction (I63) caused by embolism of the cerebral arteries (I63.4) was diagnosed the most often.

5. Most deaths after stroke occurred among women.

6. Most of the deaths occurred among the residents of rural areas.

7. Women continued their treatment, both in the Rehabilitation Ward and in the Nursing and Care Ward.

Taking into account the results of the study, it can be concluded that primary stroke prevention is the only effective measure for reducing morbidity and premature mortality in the population [72]. An important role is played by general practitioners, because their activities, such as health education, screening tests and early treatment, can increase public awareness and ensure effective control of risk factors for stroke. It is also necessary to further develop the network of stroke wards in order to reduce the risk of death and disability, by ensuring treatment options using state-of-the-art medical procedures [74]. Owing to lesssevere post-stroke complications, early rehabilitation, shorter hospitalisation and early secondary prevention, it will be possible to reduce treatment costs and absences from work $[73,75,76]$.

\section{REFERENCES}

1. Cendrowski W. Epidemiologia naczyniowych udarów mózgu [Epidemiology of cerebrovascular accidents] (in:) Udary naczyniowe mózgu diagnostyka i leczenie [Cerebrovascular accidents - diagnosis and treatment], ed. J. Majkowski, Wydawnictwo Lekarskie PZWL, Warsaw 1998, 14. (in Polish)

2. Słowik A, Wnuk M, Dziedzic T, Pera J. Niedokrwienny udar mózgu. Choroby naczyniowe układu nerwowego [Ischemic stroke. Vascular diseases of the nervous system] (in:) Neurologia. Kompendium [Neurology. A compendium], ed. Kozubski W. PZWL, 1st edition, Warsaw 2014, 309, 310, 315-317. (in Polish)

3. Sorensen AG, Ay H. Transient ischemic attack: definition, diagnosis, and risk stratification, Neuroimaging Clin N Am. 2011;21(2): 303-313.

4. Robbins NM, Swanson RA. Opposing effects of glucose on stroke and reperfusion injury: acidosis, oxidative stress, and energy metabolism. Stroke. 2014; 45(6): 1881-6.

5. Lo EH. A new penumbra: transitioning from injury into repair after stroke. Nat Med. 2008; 14(5): 497-500.

6. Słowik A, Wnuk M, Dziedzic T, Pera J. Niedokrwienny udar mózgu. Choroby naczyniowe układu nerwowego [Ischemic stroke. Vascular diseases of the nervous system] (in:) Neurologia. Podręcznik dla studentów medycyny [Neurology. A course book for medicine students] eds. Kozubski W, Liberski P, PZWL, Vol. 2, Warsaw 2013, 475, 473, 474, 483-485. (in Polish)

7. Prusiński A. Neurologia praktyczna [Practical neurology], 3rd edition, Wydawnictwo Lekarskie PZWL, Warsaw 2005, 209-211. (in Polish)

8. Mazur R, Książkiewicz B. Symptomatologia kliniczna ostrych udarów naczyniowych mózgu [Clinical symptomatology of acute cerebrovascular accidents] (in:) Udary naczyniowe mózgu diagnostyka i leczenie [Cerebrovascular accidents - diagnosis and treatment] ed. J. Majkowski, Wydawnictwo Lekarskie PZWL, Warsaw 1998, 28. (in Polish)

9. Głuszek J. Czynniki ryzyka udaru mózgu i prewencja pierwotna [Stroke risk factors and preliminary prevention] (in:) Życie po udarze w podejściu holistycznym [A holistic approach to life after a stroke], ed. J. Twardowska-Rajewicz, Publishing Press of the Adam Mickiewicz University, Poznań 2010, 37-43. (in Polish)

10. Chalmers J, MacMahon S, Anderson C, Neal B, Rodgers A. Ciśnienie tętnicze a udar mózgowy. Poradnik klinicysty [Blood pressure and stroke. A clinician's guidebook], Via Medica, Gdańsk 1996, 14-16. (in Polish).

11. Raport z ogólnopolskiego badania ankietowego na temat postaw wobec palenia tytoniu [A report on the Polish nation-wide questionnaire survey on attitudes to tobacco smoking], TNS Polska for the Chief Sanitary Inspectorate, Warsaw 2015. (in Polish) 
12. Levine DA, Wadley VG, Langa KM, Unverzagt FW, Kabeto MU, Giordani B, Howard G, Howard VI, Cushman M, Judd SE, Galecki AT. Risk Factors for Poststroke Cognitive Decline The REGARDS Study (Reasons for Geographic and Racial Differences in Stroke). Stroke. 2018; 49: 987-994.

13. Global Health Estimates 2016: Deaths by Cause, Age, Sex, by Country and by Region, 2000-2016. Geneva, World Health Organization; 2018, http://www.who.int/en/news-room/fact-sheets/detail/the-top10 -causes-of-death

14. Lopez AD, Mathers CD, Ezzati M, et al. Global and regional burden of disease and risk factors, 2001: systematic analysis of population health data. Lancet 2006; 367: 1747-1757.

15. Mozaffarian D, Benjamin EJ, Go AS, Arnett DK, Blaha MJ, Cushman, M, et al. Heart disease and stroke statistics-2016 update a report from the american heart association. Circulation. 2015; 133: e38-360.

16. Doehner W, Schenkel J, Anker SD, Springer J, Audebert HJ. Overweight and obesity are associated with improved survival, functional outcome, and stroke recurrence after acute stroke or transient ischaemic attack: observations from the TEMPiS trial. Eur Heart J. 2013; 34(4): $268-277$.

17. Health at a Glance: Europe 2016 - State of Health in the EU Cycle, OECD/EU, Paris 2016.

18. Global Burden of Stroke, The Atlas of Heart Disease and Stroke, WHO, Geneva, 2016, 52, http://www.who.int/cardiovascular_diseases/ resources/atlas/en/.

19. Della-Morte D, Guadagni F, Palmirotta R, et al. Genetics of ischemic stroke, stroke-related risk factors, stroke precursors and treatments. Pharmacogenomics. 2012; 13(5): 595-613.

20. Bourgeais V. Causes of death in 2013. Over a million persons died in the EU from a heart attack or a stroke. Cause of 1 in every 5 deaths in the EU, Eurostat Press Office, 91/2016 - May 2016, http://ec.europa. eu/eurostat/documents/2995521/7247552/3-04052016-BP-EN.pdf/ fd9d9755-e9d0-4389-a0e8-8fa879efa375.

21. Sytuacja zdrowotna ludności Polski i jej uwarunkowania [The health status of the Polish population and its determinants], eds. B. Wojtyniak, P. Goryński. The National Institute of Public Health - National Institute of Hygiene, Warsaw 2016 (in Polish).

22. ICD-10 International Statistical Classification of Diseases and Related Health Problems 10th Revision, Vol. I, issue 2008, WHO, pp. 326-327.

23. Ludność w 2016 roku w powiecie kraśnickim [Population in 2016 in the Kraśnik District], Statistics Poland, Branch in Lublin, http:// lublin.stat.gov.pl/files/gfx/lublin/pl/defaultstronaopisowa/925/1/1/17 p04.pdf (in Polish).

24. Armitage P. Metody statystyczne w badaniach medycznych [Statistical methods in medical studies]. PZWL Warsaw 1978. (in Polish)

25. Sawicki F.: Elementy statystyki dla lekarzy [Elements of statistics for medical doctors]. PZWL Warsaw 1982. (in Polish)

26. Przygotowanie szpitali do leczenia pacjentów z udarem mózgu. Raport Najwyższej Izby Kontroli [Readiness of hospitals for treating stroke patients. The Supreme Chamber of Control's Report]. Warsaw 2016: 7. (in Polish)

27. Udary mózgu - konsekwencje społeczne i ekonomiczne [Strokes social and economic consequences], ed. M. Gałązka-Sobotka, Lazarski University, Warsaw 2013; (in Polish)

28. Ingeman A, Andersen G, Thomsen RW, Hundborg HH, Rasmussen $\mathrm{HH}$, Johnsen SP. Lifestyle Factors and Early Clinical Outcome in Patients With Acute Stroke A Population-Based Study, Stroke. 2017; 48: 611-617.

29. Zdrowie i zachowanie zdrowotne mieszkańców Polski w świetle Europejskiego Ankietowego Badania Zdrowia (EHIS) 2014 [Health and health-related behaviors of people living in Poland in the light of the European Health Interview Survey (EHIS) 2014], Statistics Poland, Warsaw 2015, 6-7.

30. Andersen KK, Olsen TS. The obesity paradox in stroke: lower mortality and lower risk of readmission for recurrent stroke in obese stroke patients. Int J Stroke. 2015; 10(1): 99-104

31. Semins MJ, Shore AD, Makary MA, Weiner J, Matlaga BR. The impact of obesity on urinary tract infection risk. Urology. 2012; 79: 266-269.

32. Olsen TS, Dehlendorff C, Petersen HG, Andersen KK. Body mass index and poststroke mortality. Neuroepidemiol. 2008; 30: 93-100.

33. Cardiovascular Disease and Diabetes: Policies for Better Health and Quality of Care, OECD Health Policy Studies, Paris 2015: 14. http:// dx.doi.org/10.1787/9789264233010-en.

34. Policy paper dla ochrony zdrowia na lata 2014-2020. Krajowe ramy strategiczne. Narodowa Strategia Spójności [Policy paper for health protection for 2014-2020. The National Strategic Framework. The National Cohesion Strategy], Warsaw 2014, 34-35. (in Polish)
35. Vemmos K, Ntaios G, Spengos K, Savvari P, Vemmou A, Pappa T, et al. Association between obesity and mortality after acute first-ever stroke: the obesity-stroke paradox. Stroke. 2011; 42: 30-36.

36. Jing J, Pan Y, Zhao X, et al. Prognosis of Ischemic Stroke With Newly Diagnosed Diabetes Mellitus According to Hemoglobin A1c Criteria in Chinese Population. Stroke. 2016; 47: 2038-2044.

37. Smith EE, Shobha N, Dai D, Olson DM, Reeves MJ, Saver JL, et al. Risk score for in-hospital ischemic stroke mortality derived and validated within the Get With The Guidelines-Stroke Program. Circulation. 2010; 122: 1496-1504.

38. Furie KL, Kasner SE, Adams RJ, Albers GW, Bush RL, et al. Guidelines for the prevention of stroke in patients with stroke or transient ischemic attack: a guideline for healthcare professionals from the American Heart Association/American Stroke Association. Stroke. 2011; 42: 227-276.

39. Boan AD, Lackland DT, Ovbiagele B. Lowering of blood pressure for recurrent stroke prevention. Stroke. 2014; 45: 2506-2513.

40. Kunst AE, Amiri M, Janssen F. The decline in stroke mortality: exploration of future trends in 7 Western European countries. Stroke 2011; 42: 2126-30.

41. Burke SN, Barnes CA. Neural plasticity in the ageing brain, Nat Rev Neurosci. 2006; 1(7): 30-40.

42. Park DC, Reuter-Lorenz P. The adaptive brain: aging and neurocognitive scaffolding. Annu Rev Psychol. 2009; 60: 173-196.

43. Reuter-Lorenz PA, Park DC. How does it STAC up? Revisiting the scaffolding theory of aging and cognition. Neuropsychol Rev. 2014; 24: 355-370.

44. „Prognoza ludności na lata 2008-2035” [Population forecast for 20082035], Statistics Poland, Warsaw 2009, pp. 308-310. (in Polish)

45. Winovich DT, Longstreth WT, Arnold AM, Varadhan R, Al Hazzouri AZ, et al. Factors Associated With Ischemic Stroke Survival and Recovery in Older Adults, Stroke, 2017; 48: 1818-1826. (in Polish)

46. Postepowanie w Ostrym Udarze Niedokrwiennym Mózgu: Raport zespołu ekspertów Narodowego Programu Profilaktyki i Leczenia Udaru Mózgu [Procedures taken in acute ischemic stroke cases: A report of an expert group as part of the National Stroke Prevention and Treatment Programme]. Neurol Neurochir Pol. 1999; 33(4): 13-60.

47. Aboderin I, Venables G. Stroke management in Europe. Pan European Consensus Meeting on Stroke Management. J Intern Med. 1996; 240: $173-180$.

48. Kwolek A. Historia rehabilitacji neurologicznej w Polsce [The history of neurological rehabilitation in Poland]. In: Jandziś S, Kwolek A. Rozwój rehabilitacji w wybranych specjalnościach medycznych w Polsce [Rehabilitation development in selected medical specializations in Poland]. Rzeszów, Publishing House of the University of Rzeszów 2014; 109-132. (in Polish)

49. Fischer U, de Sousa D, Norrving B, Caso V. Status and Perspectives of Acute Stroke Care in Europe. Stroke. 2018; 49: 2281-2282.

50. „Program Profilaktyki i Leczenia Chorób Układu SercowoNaczyniowego POLKARD na lata 2017-2020" [The National Programme for Prevention and Treatment of Cardiovascular Diseases POLKARD for 2017-2020], Ministry of Health, Warsaw 2017, 18-19. https://www.gov.pl/zdrowie/program-profilaktyki-i-leczenia-chorobukladu-sercowo-naczyniowego-polkard. (in Polish)

51. Arnao V, Popovic N, Caso V. How is stroke care organized in Europe? Press Med. 2016; 45: 399-408.

52. „Ogólnopolski Program Profilaktyki Chorób Naczyń Mózgowych (ICD 10:I60-I69)" na lata 2017-2020, opracowany i współfinansowany ze środków Unii Europejskiej w ramach Programu Operacyjnego Wiedza Edukacja Rozwój [The National Stroke Prevention and Treatment Programme (ICD 10:I60-I69) for 2017-2020, developed and co-financed from EU resources as part of the Knowledge, Education, Development Operational Programme], pp. 4-5. (in Polish)

53. Di Carlo A, Pezzella FR, Fraser A, MA; Bovis F, Baeza J, McKevitt Ch, BoazA, Heuschmann P, Wolfe ChDA, Inzitari D. Methods of Implementation of Evidence-Based Stroke Care in Europe. European Implementation Score Collaboration. Stroke. 2015; 46: 2252-2259.

54. https://eso-stroke.org/eso-east/.

55. Norrving B. The 2006 Helsingborg Consensus Conference on European Stroke Strategies: Summary of conference proceedings and background to the 2nd Helsingborg Declaration. Int J Stroke 2007; 2: 139-43.

56. Wiszniewska M, Kobayashi A, Członkowska A. Postępowanie w udarze mózgu Skrót Wytycznych Grupy Ekspertów Sekcji Chorób Naczyniowych Polskiego Towarzystwa Neurologicznego z 2012 roku [Procedures taken in stroke cases. Abbreviated guidelines of an Expert Group of the Vascular Diseases Section of the Polish Neurological Society developed in 2012], Polski Przegląd Neurologiczny [The Polish Neurological Review], 2012; 8(4): 161-175. (in Polish) 
57. Liang J, Gao P, Lin Y, Song H, Sui QB. Susceptibility-weighted imaging in post-treatment evaluation in the early stage in patients with acute ischemic stroke. J Inter Med Res. 2019; 47(1): 196-205.

58. Łabuz-Roszak B, Starostka-Tatar A, Lasek-Bal A, Gierlotka M, Gąsior M, Skrzypek M. Diagnostics, treatment and secondary prevention of ischemic stroke in the Silesian Province, Poland between 2009 and 2015. Neurologia i Neurochirurgia Polska [Polish Neurology and Neurosurgery], 2018; 52(2): 235-242. (in Polish)

59. Khatib R, Jawaada AM, Arevalo YA, Hamed HK, Mohammed SH, Huffman MD. Implementing Evidence-Based Practices for Acute Stroke Care in Low- and Middle-Income Countries. Curr Atheroscler Rep. 2017; 19(12)

60. Gache K, Leleu H, Nitenberg G, Woimant F, Ferrua M, Minvielle E. Main barriers to effective implementation of stroke care pathways in France: a qualitative study, BMC Health Serv Res. 2014; 28(14).

61. Członkowska A, Milewska D, Ryglewicz D. The Polish experience in early stroke care. Cerebrovasc Dis. 2003; 15(1): 14-15.

62. Kaczorowski R, Murjas B, Bartosik-Psujek H. Rozwój i nowe perspektywy leczenia udarów mózgu w Polsce [Advancements and new perspectives in stroke treatment in Poland]. Med Rev. 2015; 13(4): 376-386. (in Polish)

63. Armstrong MJ. Shared decision-making in stroke: an evolving approach to improved patient care. Stroke Vasc Neurol, 2017; 2(2): 84-87.

64. Smajlović D. Strokes in young adults: epidemiology and prevention, Vascular Health and Risk Management 2015; 11: 157-164.

65. Castilla-Guerra L, Fernandez-Morenoa MC. Chronic Management of Hypertension after Stroke: The Role of Ambulatory Blood Pressure Monitoring. J Stroke. 2016; 18(1): 31-37.

66. De Havenon A, Bennett A, Stoddard GJ, Smith G, Chung L, O’Donnell S, McNally JS, Tirschwell D, Majersik JJ. Determinants of the impact of blood pressure variability on neurological outcome after acute ischaemic stroke. Stroke Vascular Neurol. 2017; 2(1): 1-6.
67. Appleton JP, Sprigg N, Bath PM. Blood pressure management in acute stroke, Stroke Vasc Neurol. 2016; 1(2): 72-82.

68. Kapral MK, Laupacis A, Phillips SJ, et al. Stroke care delivery in institutions participating in the Registry of the Canadian Stroke Network. Stroke. 2004; 35(7): 1756-1762.

69. Brittain KR, Shaw $\mathrm{C}$. The social consequences of living with and dealing with incontinence--a carers perspective. Soc Sci Med. 2007; 65(6): 1274-1283.

70. Litwin T, Członkowska A. Udary mózgu - wprowadzenie [Strokes - An introduction]. In: Stępień A. (ed.). Neurologia [Neurology], Warsaw, Medical Tribune Polska 2014; 2: 171-188. (in Polish)

71. Litwin T, Członkowska A. Ostre niedokrwienie mózgu - udar niedokrwienny i przemijające niedokrwienie mózgu [Acute cerebral ischemia - ischemic stroke and temporary cerebral ischemia]. In: Stępień A. (ed.) Neurologia [Neurology], Warsaw, Medical Tribune Polska 2014; 2: 189-215. (in Polish)

72. Kronish IM, Goldfinger JZ, Negron R, Fei K, Tuhrim S, Arniella G, Horowitz CR. Effect of Peer Education on Stroke Prevention The Prevent Recurrence of All Inner-City Strokes Through Education Randomized Controlled Trial. Stroke. 2014; 45: 3330-3336.

73. Kissela BM, Khoury JC, Alwell K, et al. Age at stroke: temporal trends in stroke incidence in a large, biracial population. Neurology. 2012; 79(17): 1781-1887.

74. Chwojnicki K, Ryglewicz D, Wojtyniak B, Zagożdżon P, Członkowska A, Jędrzejczyk T, Karaszewski B, Kozera G, Gierlotka M, Ezzati M, Zdrojewski T. Acute Ischemic Stroke Hospital Admissions, Treatment, and Outcomes in Poland in 2009-2013. Front Neurol. 2018; 9: 134

75. Mu F, Hurley D, Betts KA, et al. Real-world costs of ischemic stroke by discharge status. Curr Med Res Opin. 2017; 33(2): 371-378.

76. Heuschmann PU, Wiedmann S, Wellwood I, Rudd A, Di Carlo A, Bejot Y, Ryglewicz D, Rastenyte D, Wolfe CD. European Registers of Stroke. Three-month stroke outcome: the European Registers of Stroke (EROS) investigators. Neurology. 2011; 76: 159-165. 